\title{
Adult Craniopharyngioma
}

National Cancer Institute

\section{Source}

National Cancer Institute. Adult Craniopharyngioma. NCI Thesaurus. Code C4010.

A craniopharyngioma that occurs during adulthood. It can be either adamantinomatous or papillary. The papillary histologic variant occurs virtually exclusively in adults. Clinical signs and symptoms include visual disturbances and endocrine deficiencies. 